\title{
How Gameful Experience Affects Public Knowledge, Attitudes, and Practices Regarding COVID-19 Among the Taiwanese Public: Cross-sectional Study
}

Li-Hsun Peng ${ }^{1}$, PhD; Ming-Han Bai $^{2}$, MSc

${ }^{1}$ Department of Creative Design, National Yunlin University of Science and Technology, Douliou, Yunlin, Taiwan

${ }^{2}$ Graduate School of Design, National Yunlin University of Science and Technology, Douliou, Yunlin, Taiwan

Corresponding Author:

Ming-Han Bai, MSc

Graduate School of Design

National Yunlin University of Science and Technology

123 University Road

Section 3

Douliou, Yunlin, 640301

Taiwan

Phone: 886961055900

Email: minghan.bai@gmail.com

\section{Abstract}

Background: In 2019, with the COVID-19 pandemic sweeping across the globe, public health systems worldwide faced severe challenges. Amid the pandemic, one simulation game, Plague Inc., has received substantial attention. This game has indirectly drawn greater public attention to public health issues by simulating pathogen transmission and disease symptoms.

Objective: Against this backdrop, this research investigates whether the gameful experience of Plague Inc. has indirectly affected public knowledge, attitudes, and practices (KAP) regarding COVID-19.

Methods: An online survey was conducted through social networking services in Taiwan from May 6-28, 2020.

Results: A total of 486 subjects participated in this study, of which 276 (56.8\%) had played Plague Inc. This study had several findings. First, participants who had played Plague Inc. demonstrated higher levels of knowledge ( $P=.03$, median 7, IQR 7-8) and attitudes $(P=.007$, median 8, IQR 7-8) than participants who had not played Plague Inc. (knowledge: median 7, IQR 6-8; attitude: median 7, IQR 6-8). Second, there was a significant correlation between creative thinking $(\rho=.127, P=.04)$ and dominance ( $\rho=.122, P=.04)$ in attitude. Finally, there was a significant correlation between creative thinking $(\rho=.126, P<.001)$ and dominance $(\rho=.119, P=.049)$ in practice.

Conclusions: Serious games highlighting the theme of pathogen transmission may enhance public knowledge and attitudes regarding COVID-19. Furthermore, the creative thinking and dominance involved in gameful experiences may act as critical factors in public attitudes and practices regarding COVID-19. These findings should be further verified through experimental research in the future.

(JMIR Serious Games 2021;9(2):e26216) doi: 10.2196/26216

\section{KEYWORDS}

COVID-19; knowledge; attitude; practice; serious game; gameful experience

\section{Introduction}

At the end of 2019, an outbreak of pneumonia of unknown cause was detected in Wuhan, China, and it was quickly discovered to be caused by a novel coronavirus, SARS-CoV-2 [1]. On January 21, 2020, Taiwan reported the first confirmed COVID-19 case overseas [2]. As of March 21, 2021, more than
270 million diagnosed cases and 1 million deaths had been reported globally [3]. Although vaccines are considered one of the means of prevention of infectious diseases such as COVID-19, it takes time to verify their safety before they can be brought to market [4].

In the face of the severe threat of COVID-19, implementing controls on health care services and communities has been 
deemed an effective strategy [5]. In addition, a general population with higher levels of knowledge regarding pathogens is considered more likely to adopt the correct preventive measures and thereby reduce the prevalence rate of infections $[6,7]$. Therefore, many governments in the world have proactively provided the latest valid COVID-19 information and guidelines on epidemic prevention to their citizens using mainstream media or social media [8].

Promoting public attention toward health and medical care using game feedback has been proposed, as it helps the public understand possible threats to health and medical challenges when facing a difficult situation related to public health and safety [9]. The Centers for Disease Control and Prevention in the United States and the University of Derby in the United Kingdom have also attempted to impart knowledge about virus transmission and microbiology using educational games [10,11].

Teaching medical knowledge through the form of games has been found to be as effective as traditional text-based teaching methods [12]. In addition to teaching accurate information in a guided and context-based manner, incorporating knowledge pertaining to food and drug safety into video games has been proven to effectively raise the level of relevant knowledge among youngsters $[13,14]$. Moreover, teaching cardiopulmonary resuscitation through serious games has also been shown to result in a higher retention rate of knowledge and skills $[15,16]$. Teaching hand hygiene and diarrhea prevention methods through educational games has been confirmed to enhance users' awareness and practice of public health habits $[17,18]$. Although serious games have potential for use in medical education and promote proactiveness in learners, it is necessary to strike a balance between instructional theories, educational content, and game interaction to effectively enhance learning performance [19].

Plague Inc. is a pathogen simulation game that attracts widespread public attention whenever a pandemic breaks out. This game introduces the public to epidemiology in an unconventional way, allowing users to obtain knowledge of the transmission and characteristics of pathogens through gaming [20]. As a form of new media, Plague Inc. employs simple graphics but has diverse charts and functions (Figure 1) [21]. The public may acquire scientific knowledge through intuitive simulation games. In addition, students may also learn about and analyze pathogen transmission and disease symptoms through gameful experiences [22,23].

However, the behaviors that players exhibit while playing games are not just intended for entertainment and recreation. Players' personality traits are believed to be projected onto their behavior and choices during a game [24,25]. In particular, educational issue-based games not only integrate common gaming elements such as points, badges, and rankings into their design but also offer experiences that enhance extrinsic and intrinsic motivations for players [26-29]. Gamification technology has been found to have a positive effect on health and well-being [30]. Moreover, it has also been deemed to have an important mediating role in health behaviors [31]. Gamification technology has proven to be an effective tool for clinical nursing skill training. However, users' feelings and attitudes toward the gamification content should be considered [32]. In addition, both gamification technologies and gameful experience can result in psychological or behavioral changes [33].

Figure 1. Game guild levels of Plague Inc.

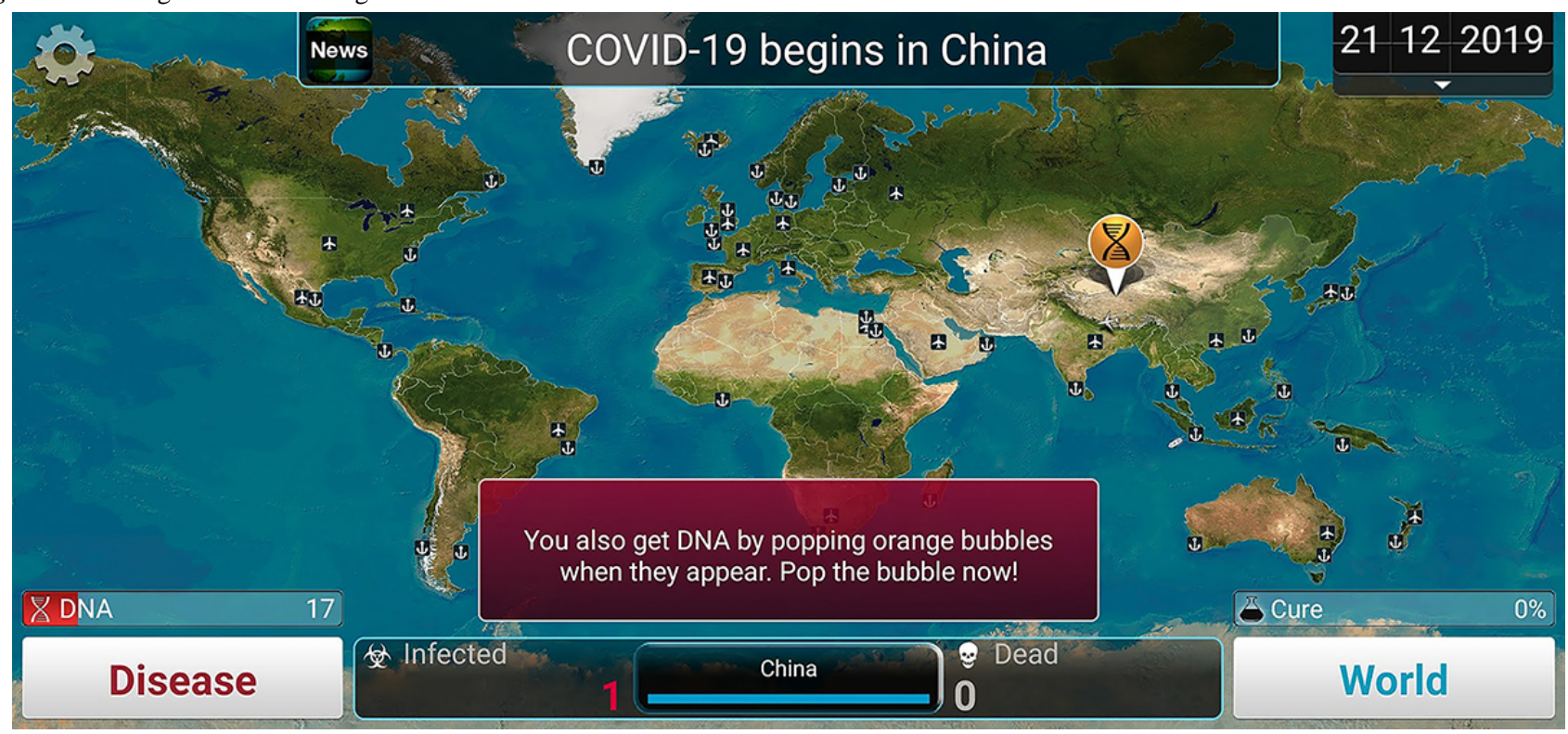

\section{Objective}

This research aims to investigate and explore the effects of gameful experience of Plague Inc. on public knowledge, attitudes, and practices (KAP) regarding COVID-19 through online surveys.

\section{Methods}

\section{Study Design}

This research used a cross-sectional study design to explore the impact of Taiwanese gameful experiences on KAP regarding COVID-19. 
From May 6-28, 2020, we collected data through an online survey, the link to which was published on social networking services (such as Facebook, PTT Bulletin Board System, internet game forums).

The target population was residents of Taiwan, the population of which was 23,591,920 [34] in April 2020. We used the sample size calculator provided by Rao Soft Inc and selected a 95\% confidence level, 5\% margin of error, and 23,591,920 population size; the calculated recommended sample size was 385.

This study was conducted in line with the Declaration of Helsinki. All participants were anonymous and provided informed consent. They clearly understood the research content in the online questionnaire [35]. The survey information sheet contained an introduction, background, goals, anonymity statement, and questionnaire descriptions. The average survey completion time was 5 minutes.

\section{Survey Instrument}

The online survey consisted of four parts: demographics, KAP of COVID-19, game experience of Plague Inc., and a gameful experience scale.

The first part includes demographic variables such as gender, age range, education, living arrangement, and occupation.

The second part pertains to the revised COVID-19 scale. The scale contains 27 questions on the three dimensions of COVID-19-namely, knowledge, attitudes, and practices. Each dimension has 9 questions, with 0 as the lowest score and 9 as the highest. Respondents are required to select "Yes," "No," or "Uncertain" for each question. For each correctly answered question, one point is added to the total score of the dimension that contains the question. Moreover, no point was awarded for questions with an incorrect or "Uncertain" answer.

The original scale was used to discuss the KAP regarding Middle East respiratory syndrome coronavirus (MERS-CoV) during the annual Hajj pilgrimage [36], and it was adjusted and translated to Chinese. In addition, five experts in clinical medical treatment and public health were invited to examine the questionnaire content to ensure the questionnaire's validity. The questionnaire is shown in Table 1.

The third part is about gameful experience of Plague Inc., including "ever played Plague Inc.," "time since last played," and "total playtime ranges." In this part, screenshots were used to describe the game's content (Figure 2).

The fourth part is the gameful experience scale consisting of 27 questions, divided into 6 dimensions: enjoyment, absorption, creative thinking, activation, absence of negative affect, and dominance [37]. The scale is a 5-point Likert scale, with options from 1 (strongly disagree) to 5 (strongly agree).

This scale was also used in nursing-related research and was considered to demonstrate excellent reliability and validity. It can be used to evaluate nursing students' gaming experiences during training [38]. Three practitioners from the gaming industry were invited to give suggestions on modifying the questionnaire after translation. 
Table 1. Questionnaire of knowledge (K), attitudes (A), and practices (P) regarding COVID-19.

\begin{tabular}{|c|c|}
\hline Questions & Correct response $(\%)$ \\
\hline K1. The incubation period of COVID-19 is from 2 to 14 days. & 81.3 \\
\hline K2. Stomach cramps, loss of appetite, nausea, and vomiting are the main symptoms of COVID-19. & 38.9 \\
\hline K3. People with comorbidities are more likely to be infected. & 77.0 \\
\hline K4. COVID-19 spreads through close contact with an infected person, such as caring for and/or living with them. & 94.7 \\
\hline K5. The primary source of COVID-19 is a plant. & 89.1 \\
\hline K6. Antibiotics are the first line of treatment. & 52.5 \\
\hline K7. Vaccinations for COVID-19 are available. & 91.4 \\
\hline K8. COVID-19 can be fatal. & 96.9 \\
\hline K9. Isolation of patients with COVID-19 is essential to ensure effective implementation of infection control measures. & 99.0 \\
\hline A1. Do you agree that there is no risk of contracting COVID-19 when going out and traveling? & 83.7 \\
\hline A2. Do you agree that taking antibiotics can treat COVID-19? & 48.8 \\
\hline A3. Do you agree that pain medication and/or fever medications cannot relieve COVID-19 symptoms? & 38.7 \\
\hline A4. Do you agree that washing your hands with soap and water for at least 30 seconds can prevent disease transmission? & 95.7 \\
\hline $\begin{array}{l}\text { A5. Do you agree that avoiding undercooked meat or food prepared under unsanitary conditions can prevent the transmission } \\
\text { of disease? }\end{array}$ & 87.4 \\
\hline A6. Do you agree that avoiding contact with live animals such as bats can prevent the spread of disease? & 86.6 \\
\hline A7. Do you agree that avoiding contact with ill people can prevent the spread of disease? & 97.3 \\
\hline $\begin{array}{l}\text { A8. Do you agree that before attending public gatherings or traveling, one must have the necessary information about } \\
\text { COVID-19? }\end{array}$ & 95.9 \\
\hline $\begin{array}{l}\text { A9. Do you agree that reporting COVID-19 symptoms to local health authorities is essential to prevent further disease } \\
\text { transmission? }\end{array}$ & 98.8 \\
\hline P1. At a public gathering, did you cover your mouth when sneezing/coughing? & 97.3 \\
\hline P2. At a public gathering, did you wash your hands with soap and water after sneezing/coughing? & 59.5 \\
\hline P3. At a public gathering, did you wash your hands before preparing or eating foods? & 80.7 \\
\hline P4. At a public gathering, did you wash your hands after contact with possibly contaminated surfaces or materials? & 85.0 \\
\hline P5. At a public gathering, did you avoid close contact with people when you were sick? & 91.6 \\
\hline P6. At a public gathering, did you wear a face mask in heavily crowded areas? & 96.7 \\
\hline P7. At a public gathering, did you share cups or eating utensils with other people? & 78.8 \\
\hline P8. Did you consult a health care worker during a public gathering if you had a fever, cough, or difficulty breathing? & 92.4 \\
\hline P9. At a public gathering, did you avoid direct hand contact with your eyes, nose, and mouth? & 78.0 \\
\hline
\end{tabular}


Figure 2. Screenshot of Plague Inc.

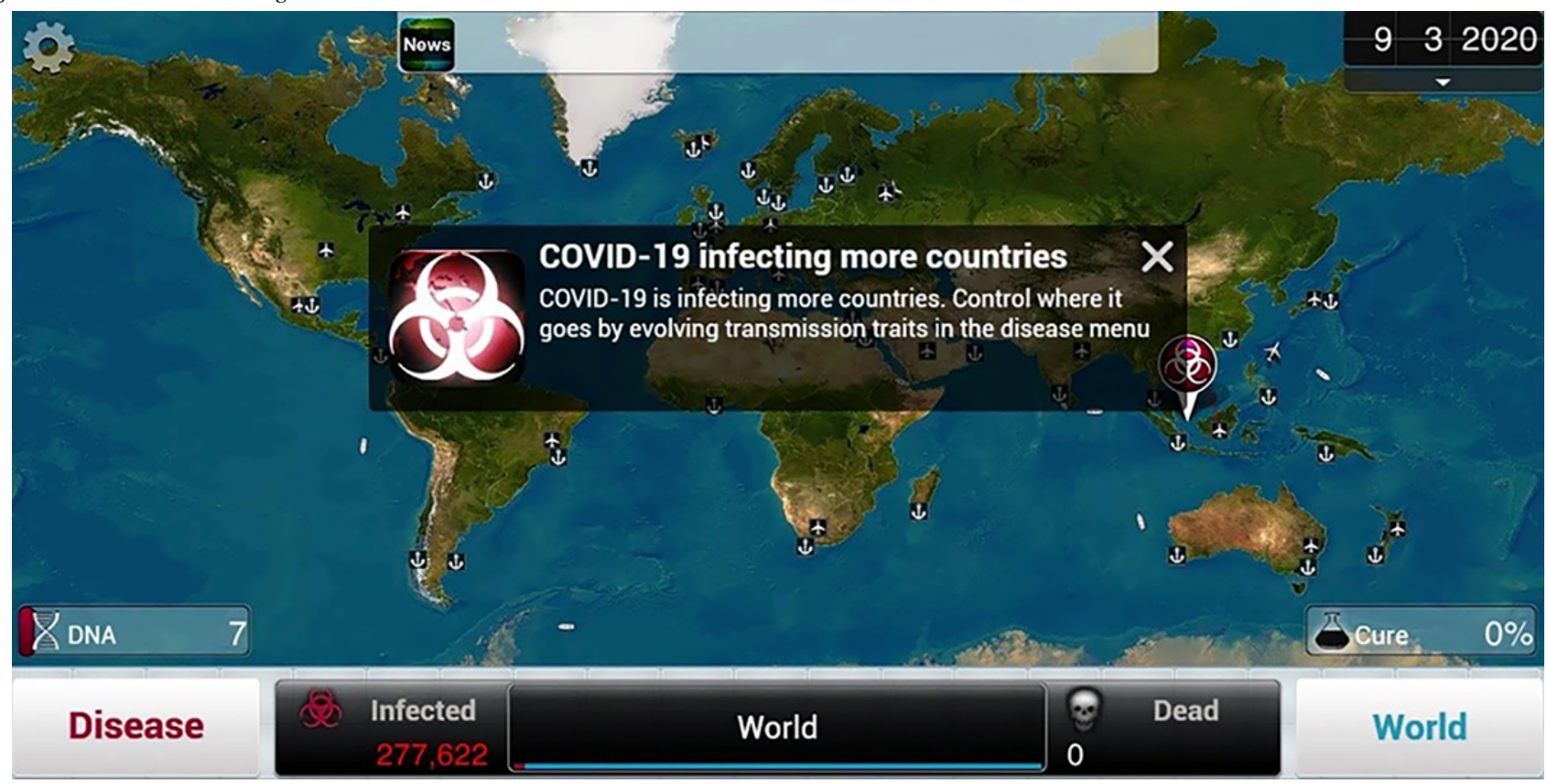

\section{Game}

Plague Inc. is a strategic simulation game that simulates how various pathogens are spread throughout the world. It was released on the App Store and Google Play in 2012. In 2014, Plague Inc: Evolved was launched on Steam, a platform for PC games.

At the beginning of each game, players can repeatedly spread new pathogens to different countries. Using DNA points in the game, players try to achieve the goal of eliminating all of mankind by employing different modes of transmission, symptoms, and abilities, and influencing the infectivity, severity, and lethality of the viruses.

Players may indirectly control the speed at which infectious pathogens spread by selecting different routes of transmission, as shown in Figure 3. In particular, the game simulates how pathogens spread via airplanes and boats, increasing the number of infected countries and individuals.

Players may change the infectivity and lethality of pathogens by selecting different symptoms, as shown in Figure 4. They may keep the death toll from ascending too rapidly by balancing infectivity and lethality, while allowing pathogens to continue spreading through infected individuals.

Plague Inc. simulates countries with different climates and latitudes. In addition, as the game progresses, vaccines will appear to prevent players from winning. Therefore, players have to use their abilities to influence the pathogen's temperature and drug resistance, as shown in Figure 5.

Figure 3. Screenshot of Plague Inc.: disease transmission.

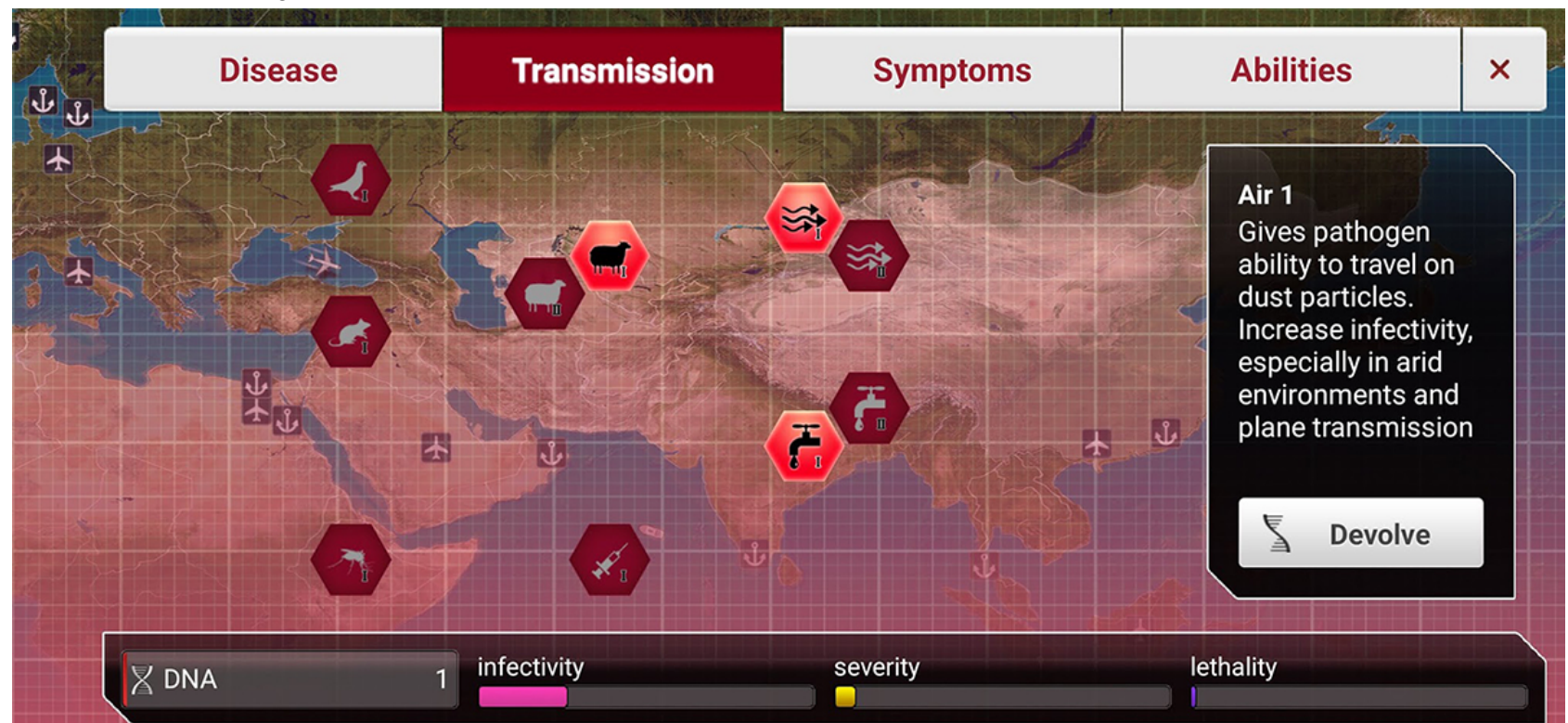


Figure 4. Screenshot of Plague Inc.: disease symptoms.

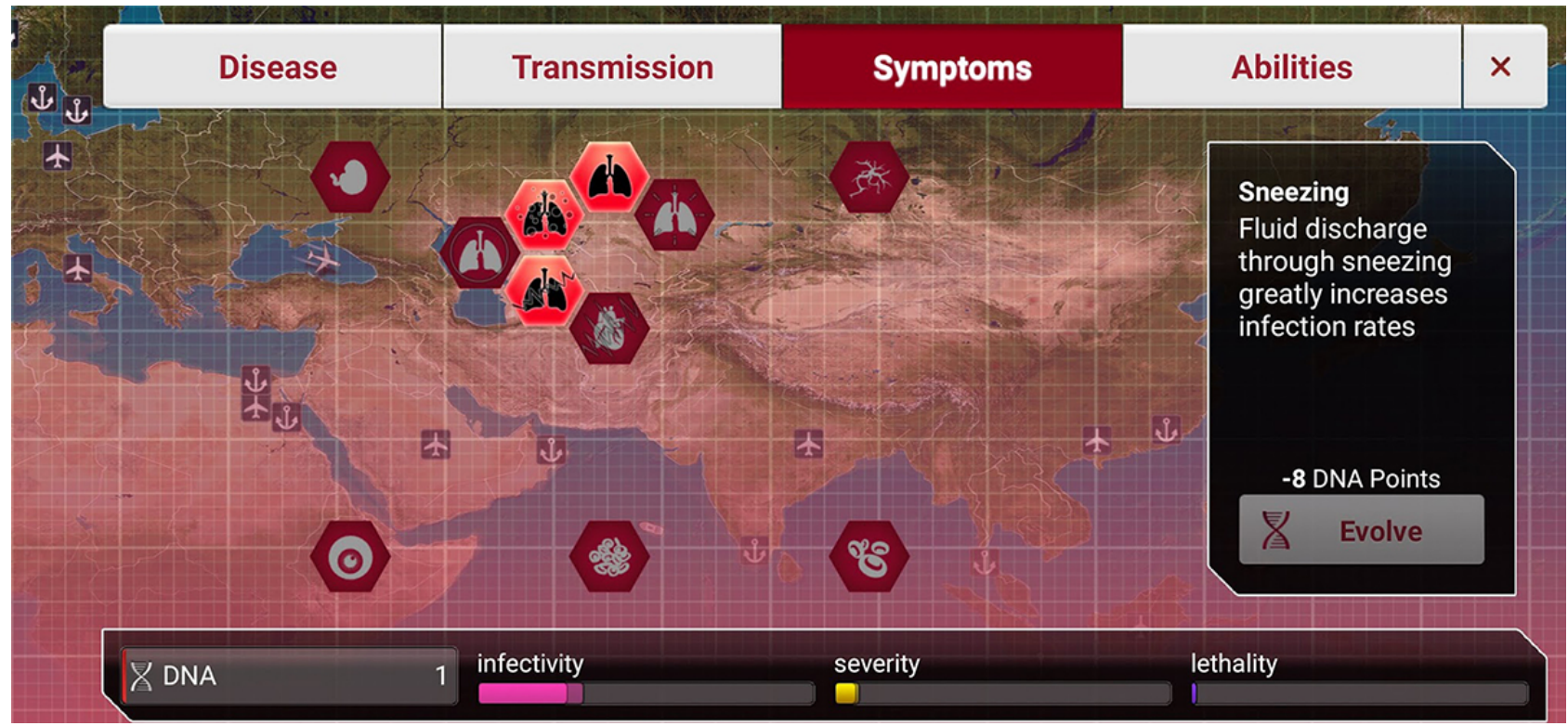

Figure 5. Screenshot of Plague Inc.: disease abilities.

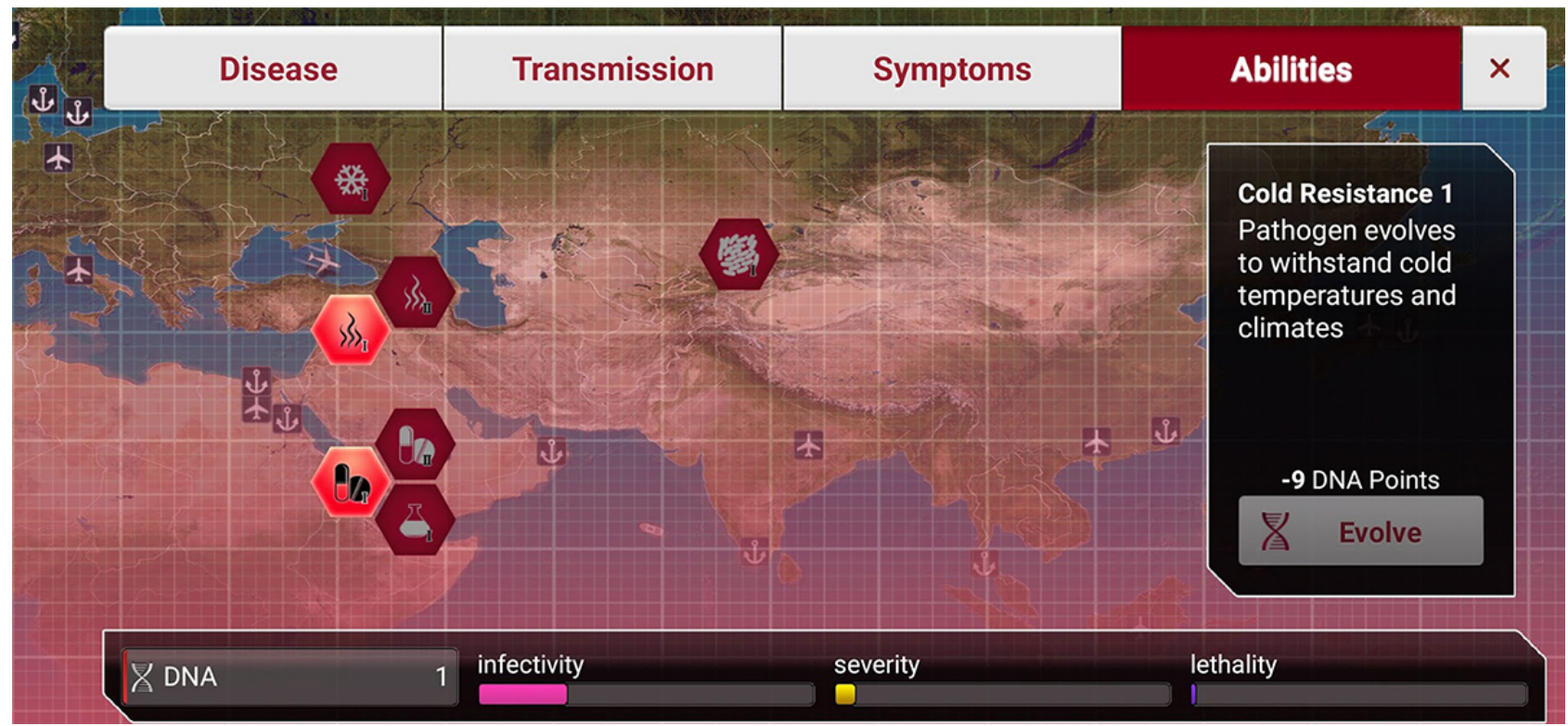

\section{Data Analysis}

Based on the normality test, this study used nonparametric statistics, the Mann-Whitney $U$ test, and the Kruskal-Wallis test to verify the KAP of COVID-19 to understand whether the KAP of COVID-19 was affected by gaming experience. In addition, we used the chi-square test to analyze whether there is a significant difference between whether participants have played Plague Inc. and their demographic characteristics and the Spearman rank correlation test to analyze the correlation between gameful experience and COVID-19 KAP.

In this study, the Cronbach $\alpha$ test was used to detect the internal consistency of the KAP of COVID-19 questionnaire and the gameful experience scale. For the KAP of COVID-19 questionnaire, Cronbach $\alpha=.82$, while Cronbach $\alpha=.994$ for the gameful experience scale; the results had acceptable internal consistency [39].

\section{Results}

A total of 486 participants were recruited for this study; demographic characteristics are shown in Table 2. Participants included $200(41.2 \%)$ women and $286(58.8 \%)$ men. The majority of participants were aged $20-29$ years $(n=323,66.5 \%)$, had a university degree $(\mathrm{n}=305,62.8 \%)$, were living with others $(n=365,75.1 \%)$, and were part of the labor force $(n=335$, $68.9 \%)$.

In total, 276 (56.8\%) participants indicated they have played Plague Inc. and 210 (43.2\%) have never played the game (Table 3). 
Table 2. Demographic characteristics $(\mathrm{N}=486)$.

\begin{tabular}{|c|c|}
\hline Variables & Participants, n (\%) \\
\hline \multicolumn{2}{|l|}{ Gender } \\
\hline Male & $286(58.8)$ \\
\hline Female & $200(41.2)$ \\
\hline \multicolumn{2}{|l|}{ Age group (years) } \\
\hline $20-29$ & $323(66.5)$ \\
\hline $30-39$ & $127(26.1)$ \\
\hline $40-49$ & $32(6.6)$ \\
\hline$\geq 50$ & $4(0.8)$ \\
\hline \multicolumn{2}{|l|}{ Education } \\
\hline High school or below & $20(4.1)$ \\
\hline University & $305(62.8)$ \\
\hline Graduate school & $161(33.1)$ \\
\hline \multicolumn{2}{|l|}{ Living arrangement } \\
\hline Alone & $121(24.9)$ \\
\hline With others & $365(75.1)$ \\
\hline \multicolumn{2}{|l|}{ Occupation } \\
\hline Labor force & $335(68.9)$ \\
\hline Non-labor force & $103(21.2)$ \\
\hline Unemployed & $48(9.9)$ \\
\hline
\end{tabular}

Table 3. Descriptive statistics regarding participants' game experience ( $\mathrm{N}=486)$.

\begin{tabular}{ll}
\hline Variables & Participants, $\mathrm{n}(\%)$ \\
\hline $\begin{array}{l}\text { Ever played } \\
\text { Yes }\end{array}$ & $276(56.8)$ \\
No & $210(43.2)$ \\
Time since last played & $26(5.3)$ \\
$<1$ week & $63(13)$ \\
$<1$ month & $83(17.1)$ \\
$<6$ months & $25(5.1)$ \\
$<1$ year & $79(16.3)$ \\
$\geq 1$ year & \\
Total playtime & $63(13)$ \\
$<1$ hour & $127(26.1)$ \\
$1-10$ hours & $86(17.7)$ \\
$\geq 10$ hours &
\end{tabular}

The chi-square test was used to examine whether there is a significant difference in the demographic characteristics of participants who have played Plague Inc. and those who have not. The analysis results are shown in Table 4.

The analysis results show significant differences in gender $(P<.001)$ and age $(P=.006)$ between participants who have and have not played Plague Inc. However, no significant difference is observed in education, living arrangement, or occupation.
In terms of gender, males who have played Plague Inc. account for a higher percentage $(196 / 286,68.5 \%)$ than those who have not $(90 / 286,31.5 \%)$, whereas more females have not played Plague Inc. (never played: 120/200, 60\%; ever played: 80/200, $40 \%)$.

As for the different age groups, among participants aged 20-29 years, more have played Plague Inc. $(195 / 323,60.4 \%)$ than not (128/323, 39.6\%); among those aged 30-39 years, more have 
played (69/127, 54.3\%) than not (58/127, 45.7\%); among those aged $40-49$ years, more have not played $(20 / 32,62.5 \%)$ than have played $(12 / 32,37.5 \%)$; and finally, among participants aged $\geq 50$ years, none have played Plague Inc. before $(4 / 4$, $100 \%)$.

Table 4. Chi-square test for demographic characteristics between those who have or have not played Plague Inc. (N=486).

\begin{tabular}{|c|c|c|c|c|c|}
\hline \multirow[t]{2}{*}{ Variables } & \multirow[t]{2}{*}{ Participants, $n$} & \multicolumn{2}{|c|}{ Ever played Plague Inc., n (\%) } & \multicolumn{2}{|c|}{ Chi-square test } \\
\hline & & Yes $(n=276)$ & No $(n=210)$ & $\chi^{2}(d f)$ & $P$ value \\
\hline Gender & & & & $39(1)$ & $<.001$ \\
\hline Male & 286 & $196(68.5)$ & $90(31.5)$ & & \\
\hline Female & 200 & $80(40)$ & $120(60)$ & & \\
\hline Age group (years) & & & & $12.1(3)$ & .006 \\
\hline $20-29$ & 323 & $195(60.4)$ & $128(39.6)$ & & \\
\hline $30-39$ & 127 & $69(54.3)$ & $58(45.7)$ & & \\
\hline $40-49$ & 32 & $12(37.5)$ & $20(62.5)$ & & \\
\hline$\geq 50$ & 4 & $0(0)$ & $4(100)$ & & \\
\hline Education & & & & $1.2(2)$ & .54 \\
\hline High school or below & 20 & $11(55)$ & $9(45)$ & & \\
\hline University & 305 & $179(58.7)$ & $126(41.3)$ & & \\
\hline Graduate school & 161 & $86(53.4)$ & $75(46.6)$ & & \\
\hline Living arrangement & & & & $1.8(1)$ & .18 \\
\hline Alone & 121 & $75(62)$ & $46(38)$ & & \\
\hline With others & 365 & $201(55.1)$ & $164(44.9)$ & & \\
\hline Occupation & & & & $3(2)$ & .22 \\
\hline Labor force & 335 & $197(58.8)$ & $138(41.2)$ & & \\
\hline Non-labor force & 103 & $57(55.3)$ & $46(44.7)$ & & \\
\hline Unemployed & 48 & $22(45.8)$ & $26(54.2)$ & & \\
\hline
\end{tabular}

The Mann-Whitney $U$ and Kruskal-Wallis tests were used to assess any differences in KAP of COVID-19 between participants who had ever or never played Plague Inc., while the Kruskal-Wallis test was used to determine whether differences in KAP of COVID-19 were related to differences in time since last played and total playtime, as shown in Table 5.

There was a statistically significant difference between knowledge and attitude regarding COVID-19 for the item of whether a participant had ever played the game Plague Inc.

The scores on questions related to knowledge of COVID-19 were lower among never-played participants (median 7, IQR 6-8) than among ever-played participants (median 7, IQR 7-8).

The scores on the questions about attitude regarding COVID-19 were lower among never-played participants (median 7, IQR 6-8) than among ever-played participants (median 8, IQR 7-8). The results indicated that the time since last played had a significant effect for the item of attitude regarding COVID-19.
The scores on the questions about attitude regarding COVID-19 were lower among never-played participants (median 7, IQR 6-8) than among those who had not played in over one year (median 8, IQR 7-9).

The results indicated that there was a significant difference in scores on the questions about attitude regarding COVID-19 among participants with different total playtimes. The scores on questions about attitude regarding COVID-19 were lower among never-played participants (median 7, IQR 6-8) than among those with a total playtime of 1-10 hours (median 8, IQR 7-8).

Spearman rank correlation was used to examine the relationship between KAP of COVID-19 and gameful experience (Table 6). The results showed that there was a significant correlation between creative thinking $(\rho=.127, P=.04)$ and dominance $(\rho=.122, P=.04)$ in attitude; in addition, there was a significant correlation between creative thinking $(\rho=.126, P<.001)$ and dominance $(\rho=.119, P=.049)$ in practice. 
Table 5. Mann-Whitney U test and Kruskal-Wallis test for determining the effect of game experience on knowledge, attitudes, and practices regarding COVID-19 (N=276).

\begin{tabular}{|c|c|c|c|c|c|c|c|c|c|}
\hline \multirow[t]{2}{*}{ Variables } & \multicolumn{3}{|c|}{ Knowledge score } & \multicolumn{3}{|l|}{ Attitude score } & \multicolumn{3}{|l|}{ Practice score } \\
\hline & Median (IQR) & Mean (SD) & $P$ value & Median (IQR) & Mean (SD) & $P$ value & Median (IQR) & Mean (SD) & $P$ value \\
\hline \multicolumn{10}{|l|}{ Ever played } \\
\hline Yes & $7(7-8)$ & $7.31(1.23)$ & .03 & $8(7-8)$ & $7.46(1.15)$ & .007 & $8(7-9)$ & $7.54(1.51)$ & .39 \\
\hline No & $7(6-8)$ & $7.07(1.2)$ & & $7(6-8)$ & $7.16(1.27)$ & & $8(7-9)$ & 7.67 (1.46) & \\
\hline \multicolumn{10}{|l|}{ Last played } \\
\hline$<1$ week & $7.5(7-8)$ & $7.58(0.99)$ & .26 & $8(7-8)$ & $7.62(0.94)$ & .02 & $8.5(7-9)$ & $8.12(1.11)$ & .18 \\
\hline$<1$ month & $7(7-8)$ & $7.3(1.24)$ & & $7(7-8)$ & $7.32(1.13)$ & & $8(7-9)$ & $7.75(1.43)$ & \\
\hline$<6$ months & $7(6-8)$ & $7.25(1.4)$ & & $8(7-8)$ & $7.4(1.24)$ & & $8(6-9)$ & 7.48 (1.48) & \\
\hline$<1$ year & $8(7-8)$ & $7.4(1)$ & & $7(6-8)$ & $7.12(1.24)$ & & $8(6.5-9)$ & $7.4(1.71)$ & \\
\hline$\geq 1$ year & $7(6-8)$ & $7.25(1.16)$ & & $8(7-9)$ & $7.68(1.08)$ & & $8(6-9)$ & $7.3(1.62)$ & \\
\hline \multicolumn{10}{|l|}{ Total playtime } \\
\hline$<1$ hour & $7(6-8)$ & $7.27(1.31)$ & .10 & $7(7-8)$ & $7.32(1.1)$ & .02 & $8(7-9)$ & $7.57(1.55)$ & .47 \\
\hline 1-10 hours & $7(6-8)$ & $7.23(1.31)$ & & $8(7-8)$ & $7.53(1.23)$ & & $8(7-9)$ & 7.63 (1.49) & \\
\hline$\geq 10$ hours & $8(7-8)$ & $7.45(1.01)$ & & $7(7-8)$ & $7.45(1.06)$ & & $8(6.75-9)$ & $7.4(1.51)$ & \\
\hline
\end{tabular}

Table 6. Spearman rank correlation of gameful experience with knowledge, attitudes, and practices regarding COVID-19 (N=324).

\begin{tabular}{|c|c|c|c|c|c|c|c|c|c|}
\hline Variables & 1 & 2 & 3 & 4 & 5 & 6 & 7 & 8 & 9 \\
\hline 1. Knowledge & $-^{\mathrm{a}}$ & - & - & - & - & - & - & - & 一 \\
\hline 2. Attitude & $.458^{\mathrm{b}}$ & - & - & - & - & - & - & - & - \\
\hline 3. Practice & .087 & $.166^{\mathrm{b}}$ & - & - & - & - & - & - & - \\
\hline 4. Enjoyment & .020 & .034 & .049 & - & - & - & - & - & 一 \\
\hline 5. Absorption & -.028 & -.082 & .031 & .115 & - & - & - & - & 一 \\
\hline 6. Creative thinking & .029 & $.127^{\mathrm{c}}$ & $.126^{\mathrm{c}}$ & $.361^{\mathrm{b}}$ & $.351^{\mathrm{b}}$ & - & - & - & 一 \\
\hline 7. Activation & .076 & .031 & .052 & $.259^{\mathrm{b}}$ & $.508^{\mathrm{b}}$ & $.396^{\mathrm{b}}$ & - & - & 一 \\
\hline 8. Absence of negative affect & .067 & -.087 & -.115 & $-.279^{\mathrm{b}}$ & .012 & $-.147^{\mathrm{c}}$ & .087 & - & - \\
\hline 9. Dominance & .003 & $.122^{\mathrm{c}}$ & $.119^{\mathrm{c}}$ & $.242^{\mathrm{b}}$ & $.422^{\mathrm{b}}$ & $.478^{\mathrm{b}}$ & $.453^{\mathrm{b}}$ & $-.141^{\mathrm{c}}$ & 一 \\
\hline
\end{tabular}

${ }^{\mathrm{a}}$ Not applicable.

${ }^{\mathrm{b}} P<.01$.

${ }^{\mathrm{c}} P<.05$.

\section{Discussion}

\section{Principal Findings}

This study determined the demographics of members of the public who have played Plague Inc. The results show that the research participants who have played Plague Inc. are mainly males aged 20-39 years. Studies in Spain and Turkey also found that gender indirectly affects game type preferences [40,41]. Research in the United States discovered that although the majority of middle-aged and older adults do not play video games, age does not affect their preference for strategic simulation games [42].

Participants who have played Plague Inc. displayed higher levels of knowledge and attitudes toward COVID-19. Health education implemented through gameful experience has been proven to effectively enhance knowledge of leptospirosis [43]. In addition, integrating gamified media into medical education courses has been shown to effectively improve knowledge and skill performance among nursing students [44-46]. Moreover, designing applications to integrate with gameful experience to explore learning performance in professional nursing education has also been proven to generate a higher level of knowledge when compared to traditional teaching methods [15].

In particular, research participants who had played Plague Inc. one year before the outbreak of the COVID-19 pandemic had higher attitude scores for COVID-19 than those who had not. Designing medical clinical instructional content as a serious game and incorporating gameful experience into training may 
effectively enhance medical knowledge and confidence among nursing students. Moreover, students may repeatedly practice in the simulated environment, and thereby develop a self-guided learning strategy [47,48]. China's research on COVID-19-related serious games also confirmed that educational games result in better performance in learning retention than online lectures [49].

Participants who have played Plague Inc. indicated higher creative thinking and dominance during their gameful experience. Their attitudes and practices regarding COVID-19 have a significant positive correlation. In addition, the creative thinking involved in gameful experience is considered to be one of the significant factors that affect learning performance [50]. Gamified learning materials have been proven to stimulate creative thinking in learners and improve their attitudes and soft skills for school subjects [51]. Moreover, simulated situations can also cultivate creative thinking and indirectly improve attitudes toward public health [52,53].

The game environment of Plague Inc. allows players to repeatedly experiment with different pathogens and features. During this process, players gain a better understanding of how to enhance the infectivity and lethality of a pathogen. The challenge experiences and strategies accumulated through playing the game may indirectly improve the players' corresponding attitudes and practices toward pathogens. Previous research has demonstrated that the reason that effective learning performance is achieved through serious games is due to the concept of experience-based learning. In addition, with game situations designed for players to repeatedly try and challenge, such games may motivate players to reflect on the content and strategize accordingly [54].

\section{Limitations}

This study has several limitations. First, the sample number may be insufficient to represent the general public of Taiwan. Second, as the survey was conducted on social networking websites, the surveys were mainly completed by males aged 20-39 years. This study lacks a broader scope of participants. Third, the research survey was conducted in May 2020; the COVID-19 pandemic was already easing in Taiwan by then.
Moreover, the government and medical units had also implemented advocacy and educational messaging through multiple channels. As such, the public had developed a basic understanding of COVID-19. Fourth, as the game investigated in this study is a strategic simulation game, research participants may indirectly represent a specific group. Finally, Plague Inc. was not designed specifically for COVID-19. In addition, the goal of the game is to infect and kill all human beings. A new version of the game, The Cure, was launched on November 11, 2020, which allows players to promote antipandemic prevention and isolation measures by roleplaying as the World Health Organization; however, the public may still be unable to acquire precise knowledge of specific viruses via this game.

\section{Future Research}

This research focuses on the relationship between public KAP regarding COVID-19 and the gameful experience of Plague Inc. However, there may be more factors that affect public KAP regarding COVID-19 other than the gameful experience of Plague Inc. Therefore, further research is required to explore possible interactions with other dimensions [31].

\section{Conclusions}

This study has demonstrated that Plague Inc. provides pathogen simulation scenarios that allow players to continuously seek challenges. Members of the public who have played Plague Inc. exhibit higher levels of knowledge and attitudes regarding COVID-19. Moreover, the creative thinking and dominance developed in the gameful experience have been found to be correlated with attitudes and practices regarding COVID-19. Reinforcing creative thinking and dominance through serious games may be a valid approach. However, further verification is required.

Finally, it is imperative to heighten public awareness of the symptoms and transmission routes of COVID-19 amid the unprecedented crisis of the current pandemic. This study suggests that new media, such as games, should be employed to help the public accumulate learning experiences regarding pathogens and further establish public KAP toward pathogens. In this manner, the public may become more heedful of public health issues in the future.

\section{Acknowledgments}

We sincerely thank all the health care workers fighting COVID-19 and all participants of this study.

\section{Authors' Contributions}

LHP dealt with conceptualization, funding acquisition, methodology, project administration, supervision, and writing (review and editing). MHB dealt with data curation, formal analysis, investigation, resources, validation, and writing the original draft. All authors have read and agreed to the published version of the manuscript.

\section{Conflicts of Interest}

None declared.

\section{References}

1. Lu H, Stratton CW, Tang Y. Outbreak of pneumonia of unknown etiology in Wuhan, China: The mystery and the miracle. J Med Virol 2020 Apr;92(4):401-402 [FREE Full text] [doi: 10.1002/jmv.25678] [Medline: $\underline{31950516}$ ] 
2. Cheng S, Chang Y, Fan Chiang Y, Chien Y, Cheng M, Yang C, et al. First case of Coronavirus Disease 2019 (COVID-19) pneumonia in Taiwan. J Formos Med Assoc 2020 Mar;119(3):747-751 [FREE Full text] [doi: 10.1016/j.jfma.2020.02.007] [Medline: 32113824]

3. COVID-19 Weekly Epidemiological Update. World Health Organization. 2021 Mar 21. URL: https://www.who.int/docs/ default-source/coronaviruse/situation-reports/20210323 weekly epi update 32.pdf [accessed 2021-03-25]

4. Kaur SP, Gupta V. COVID-19 Vaccine: A comprehensive status report. Virus Res 2020 Oct 15;288:198114 [FREE Full text] [doi: 10.1016/j.virusres.2020.198114] [Medline: 32800805]

5. Yen M, Chiu A, Schwartz J, King C, Lin Y, Chang S, et al. From SARS in 2003 to H1N1 in 2009: lessons learned from Taiwan in preparation for the next pandemic. J Hosp Infect 2014 Aug;87(4):185-193 [FREE Full text] [doi: 10.1016/j.jhin.2014.05.005] [Medline: 24996515]

6. Aburto NJ, Pevzner E, Lopez-Ridaura R, Rojas R, Lopez-Gatell H, Lazcano E, et al. Knowledge and adoption of community mitigation efforts in Mexico during the 2009 H1N1 pandemic. Am J Prev Med 2010 Nov;39(5):395-402. [doi: 10.1016/j.amepre.2010.07.011] [Medline: 20965376]

7. Lin L, Jung M, McCloud RF, Viswanath K. Media Use and Communication Inequalities in a Public Health Emergency: A Case Study of 2009-2010 Pandemic Influenza a Virus Subtype H1N1. Public Health Rep 2014 Nov 01;129(6_suppl4):49-60. [doi: $10.1177 / 00333549141296$ s408]

8. Mheidly N, Fares J. Leveraging media and health communication strategies to overcome the COVID-19 infodemic. J Public Health Policy 2020 Dec 21;41(4):410-420 [FREE Full text] [doi: 10.1057/s41271-020-00247-w] [Medline: 32826935]

9. Brox E, Fernandez-Luque L, Tøllefsen T. Healthy Gaming - Video Game Design to promote Health. Appl Clin Inform 2017 Dec 16;02(02):128-142. [doi: 10.4338/aci-2010-10-r-0060]

10. Devlin S, Cowling P, Kudenko D, Goumagias N, Nucciareli A, Cabras I. Game Intelligence. In: 2014 IEEE Conference on Computational Intelligence and Games. 2014 Presented at: 2014 IEEE Conference on Computational Intelligence and Games; August 26-29, 2014; Dortmund, Germany. [doi: 10.1109/cig.2014.6932917]

11. Robinson LA, Turner IJ, Sweet MJ. The use of gamification in the teaching of disease epidemics and pandemics. FEMS Microbiol Lett 2018 Jun 01;365(11):1 [FREE Full text] [doi: 10.1093/femsle/fny111] [Medline: 29718203]

12. Tubelo RA, Portella FF, Gelain MA, de Oliveira MMC, de Oliveira AEF, Dahmer A, et al. Serious game is an effective learning method for primary health care education of medical students: A randomized controlled trial. Int J Med Inform 2019 Oct;130:103944. [doi: 10.1016/j.ijmedinf.2019.08.004] [Medline: 31442848]

13. Crovato S, Pinto A, Giardullo P, Mascarello G, Neresini F, Ravarotto L. Food safety and young consumers: Testing a serious game as a risk communication tool. Food Control 2016 Apr;62:134-141. [doi: 10.1016/j.foodcont.2015.10.009]

14. Abraham O, Feathers A, Grieve L, Babichenko D. Developing and piloting a serious game to educate children about over - the - counter medication safety. J Pharm Health Serv Res 2019 Feb 21;10(2):235-241. [doi: 10.1111/jphs.12292]

15. Gutiérrez-Puertas L, García-Viola A, Márquez-Hernández VV, Garrido-Molina JM, Granados-Gámez G, Aguilera-Manrique G. Guess it (SVUAL): An app designed to help nursing students acquire and retain knowledge about basic and advanced life support techniques. Nurse Educ Pract 2021 Jan;50:102961. [doi: 10.1016/j.nepr.2020.102961] [Medline: $\underline{33421681]}$

16. Semeraro F, Frisoli A, Loconsole C, Mastronicola N, Stroppa F, Ristagno G, et al. Kids (learn how to) save lives in the school with the serious game Relive. Resuscitation 2017 Jul;116:27-32. [doi: 10.1016/j.resuscitation.2017.04.038] [Medline: 28476478]

17. Arbianingsih, Utario Y, Rustina Y, Krianto T, Ayubi D. Arbi Care application increases preschool children's hand-washing self-efficacy among preschool children. Enfermería Clínica 2018 Feb;28:27-30. [doi: 10.1016/s1130-8621(18)30031-7]

18. Higgins A, Hannan M. Improved hand hygiene technique and compliance in healthcare workers using gaming technology. J Hosp Infect 2013 May;84(1):32-37. [doi: 10.1016/j.jhin.2013.02.004] [Medline: 23498360]

19. Agudelo-Londoño S, Gorbanev I, Delgadillo V, Muñoz Ó, Cortes A, González RA, et al. Development and Evaluation of a Serious Game for Teaching ICD-10 Diagnosis Coding to Medical Students. Games Health J 2019 Oct 01;8(5):349-356. [doi: $10.1089 / \mathrm{g} 4 \mathrm{~h} .2018 .0101]$ [Medline: 31166817$]$

20. Mitchell S, Hamilton SN. Playing at apocalypse: Reading Plague Inc. in pandemic culture. Convergence 2017 Jan 17;24(6):587-606. [doi: 10.1177/1354856516687235]

21. Lorenzo S. H5N1 for Angry Birds: Plague Inc., Mobile Games, and the Biopolitics of Outbreak Narratives. Science Fiction Studies 2016;43(1):85. [doi: 10.5621/sciefictstud.43.1.0085]

22. Cheng SL, Egues A, Cohen-Brown G. Visualizing Medicine: Mapping Connections with Plague Inc. to Learn in the Interdisciplinary Classroom. In: Lansiquot RD, MacDonald SP, editors. Interdisciplinary Place-Based Learning in Urban Education: Exploring Virtual Worlds. Cham: Springer International Publishing; 2018:111-132.

23. Nascimento FGM, Benedetti TR, Santos AR. Use of the Pest Game Inc.: a possibility for Science Education in the days of COVID-19. BJD 2020;6(5):25909-25928. [doi: 10.34117/bjdv6n5-156]

24. Bai MH. Exploring the Relationship of Player Behavior and Personality Traits Using Simulation Game. Tainan, Taiwan: National University of Tainan; 2018.

25. Worth NC, Book AS. Dimensions of video game behavior and their relationships with personality. Computers in Human Behavior 2015 Sep;50:132-140. [doi: 10.1016/j.chb.2015.03.056] 
26. Chou YK. Actionable Gamification: Beyond Points, Badges and Leaderboards. Scotts Valley, CA, USA: CreateSpace Independent Publishing Platform; 2015.

27. Inoue A. Gamification - changes the business. Tokyo, Japan: NHK Shuppan; 2011.

28. Kyewski E, Krämer NC. To gamify or not to gamify? An experimental field study of the influence of badges on motivation, activity, and performance in an online learning course. Computers \& Education 2018 Mar;118:25-37. [doi:

10.1016/j.compedu.2017.11.006]

29. Feng Y, Jonathan Ye H, Yu Y, Yang C, Cui T. Gamification artifacts and crowdsourcing participation: Examining the mediating role of intrinsic motivations. Computers in Human Behavior 2018 Apr;81:124-136. [doi: 10.1016/j.chb.2017.12.018]

30. Johnson D, Deterding S, Kuhn K, Staneva A, Stoyanov S, Hides L. Gamification for health and wellbeing: A systematic review of the literature. Internet Interv 2016 Nov;6:89-106 [FREE Full text] [doi: 10.1016/j.invent.2016.10.002] [Medline: $\underline{30135818}]$

31. Mulcahy RF, Zainuddin N, Russell-Bennett R. Transformative value and the role of involvement in gamification and serious games for well-being. JOSM 2020 Aug 21;32(2):218-245. [doi: 10.1108/josm-05-2019-0137]

32. Gutiérrez-Puertas L, Márquez-Hernández VV, Román-López P, Rodríguez-Arrastia MJ, Ropero-Padilla C, Molina-Torres G. Escape Rooms as a Clinical Evaluation Method for Nursing Students. Clinical Simulation in Nursing 2020 Dec;49:73-80. [doi: 10.1016/j.ecns.2020.05.010]

33. Landers RN, Tondello GF, Kappen DL, Collmus AB, Mekler ED, Nacke LE. Defining gameful experience as a psychological state caused by gameplay: Replacing the term 'Gamefulness' with three distinct constructs. International Journal of Human-Computer Studies 2019 Jul;127:81-94. [doi: 10.1016/j.ijhcs.2018.08.003]

34. Latest indicators of total population. National Statistics RoCT. URL: https://eng.stat.gov.tw/point.asp?index=9 [accessed 2020-04-29]

35. World Medical Association. World Medical Association Declaration of Helsinki. Ethical principles for medical research involving human subjects. Bull World Health Organ 2001;79(4):373-374 [FREE Full text] [Medline: 11357217]

36. Alhomoud F, Alhomoud F. 'Your Health Essential for Your Hajj': Muslim pilgrims' knowledge, attitudes and practices regarding Middle East respiratory syndrome coronavirus (MERS-CoV) during Hajj season. J Infect Chemother 2017 May;23(5):286-292 [FREE Full text] [doi: 10.1016/j.jiac.2017.01.006] [Medline: 28216182]

37. Eppmann R, Bekk M, Klein K. Gameful Experience in Gamification: Construction and Validation of a Gameful Experience Scale [GAMEX]. Journal of Interactive Marketing 2018 Aug;43:98-115. [doi: 10.1016/j.intmar.2018.03.002]

38. Márquez-Hernández VV, Garrido-Molina JM, Gutiérrez-Puertas L, García-Viola A, Aguilera-Manrique G, Granados-Gámez G. How to measure gamification experiences in nursing? Adaptation and validation of the Gameful Experience Scale [GAMEX]. Nurse Educ Today 2019 Oct;81:34-38. [doi: 10.1016/j.nedt.2019.07.005] [Medline: 31319349]

39. Taber KS. The Use of Cronbach's Alpha When Developing and Reporting Research Instruments in Science Education. Res Sci Educ 2017 Jun 7;48(6):1273-1296. [doi: 10.1007/s11165-016-9602-2]

40. Dindar M. An empirical study on gender, video game play, academic success and complex problem solving skills. Computers \& Education 2018 Oct;125:39-52. [doi: 10.1016/j.compedu.2018.05.018]

41. Gómez-Gonzalvo F, Molina P, Devís-Devís J. Which are the patterns of video game use in Spanish school adolescents? Gender as a key factor. Entertainment Computing 2020 May;34:100366. [doi: 10.1016/j.entcom.2020.100366]

42. Salmon JP, Dolan SM, Drake RS, Wilson GC, Klein RM, Eskes GA. A survey of video game preferences in adults: Building better games for older adults. Entertainment Computing 2017 Jun;21:45-64. [doi: 10.1016/j.entcom.2017.04.006]

43. Azhari NN, Abdul Manaf R, Ng SW, Shakeeb Arsalaan Bajunid SFB, Mohd Gobil AR, Saad WZ, et al. Gamification, a Successful Method to Foster Leptospirosis Knowledge among University Students: A Pilot Study. Int J Environ Res Public Health 2019 Jun 14;16(12):2108 [FREE Full text] [doi: 10.3390/ijerph16122108] [Medline: 31207881$]$

44. Brull S, Finlayson S, Kostelec T, MacDonald R, Krenzischeck D. Using Gamification to Improve Productivity and Increase Knowledge Retention During Orientation. J Nurs Adm 2017 Sep;47(9):448-453. [doi: 10.1097/NNA.0000000000000512] [Medline: 28834805]

45. Roche CC, Wingo NP, Westfall AO, Azuero A, Dempsey DM, Willig JH. Educational Analytics: A New Frontier for Gamification? Comput Inform Nurs 2018 Sep;36(9):458-465 [FREE Full text] [doi: 10.1097/CIN.0000000000000455] [Medline: 29985195]

46. Wingo NP, Roche CC, Baker N, Dunn D, Jennings M, Pair L, et al. 'Playing for Bragging Rights': A Qualitative Study of Students' Perceptions of Gamification. J Nurs Educ 2019 Feb 01;58(2):79-85. [doi: 10.3928/01484834-20190122-04] [Medline: 30721307]

47. Tsopra R, Courtine M, Sedki K, Eap D, Cabal M, Cohen S, et al. AntibioGame®: A serious game for teaching medical students about antibiotic use. Int J Med Inform 2020 Apr;136:104074 [FREE Full text] [doi: 10.1016/j.ijmedinf.2020.104074] [Medline: 31926355]

48. Tan AJQ, Lee CCS, Lin PY, Cooper S, Lau LST, Chua WL, et al. Designing and evaluating the effectiveness of a serious game for safe administration of blood transfusion: A randomized controlled trial. Nurse Educ Today 2017 Aug;55:38-44. [doi: 10.1016/j.nedt.2017.04.027] [Medline: 28521248] 
49. Hu H, Xiao Y, Li H. The Effectiveness of a Serious Game Versus Online Lectures for Improving Medical Students' Coronavirus Disease 2019 Knowledge. Games Health J 2021 Jan 11:1. [doi: 10.1089/g4h.2020.0140] [Medline: $\underline{33434099]}$

50. Parra-González ME, Segura-Robles A, Romero-García C. Analysis of creative thinking and levels of student activation after a gamification experience. Educar $2020 \mathrm{Jul}$ 20;56(2):475. [doi: 10.5565/rev/educar.1104]

51. Cahyana U, Paristiowati M, Hasyrin S, Hasanah M. Development of students' creative thinking skills in chemistry using Mobile Game-Based Learning (M-GBL) with integrated creative problem-solving. In: Rahmawati Y, Taylor PC, editors. Empowering Science and Mathematics for Global Competitiveness. London: CRC Press; 2019:7.

52. Barzilai S, Blau I. Scaffolding game-based learning: Impact on learning achievements, perceived learning, and game experiences. Computers \& Education 2014 Jan;70:65-79. [doi: 10.1016/j.compedu.2013.08.003]

53. Fitzpatrick VE, Mayer C, Sherman BR. Undergraduate Public Health Capstone Course: Teaching Evidence-Based Public Health. Front Public Health 2016 Apr 18;4:70 [FREE Full text] [doi: 10.3389/fpubh.2016.00070] [Medline: 27148516]

54. Westera W. Why and How Serious Games can Become Far More Effective Accommodating Productive Learning Experiences, Learner Motivation and the Monitoring of Learning Gains. Journal of Educational Technology \& Society 2019;22(1):59-69.

\section{Abbreviations \\ KAP: knowledge, attitudes, and practices \\ MERS-CoV: Middle East respiratory syndrome coronavirus}

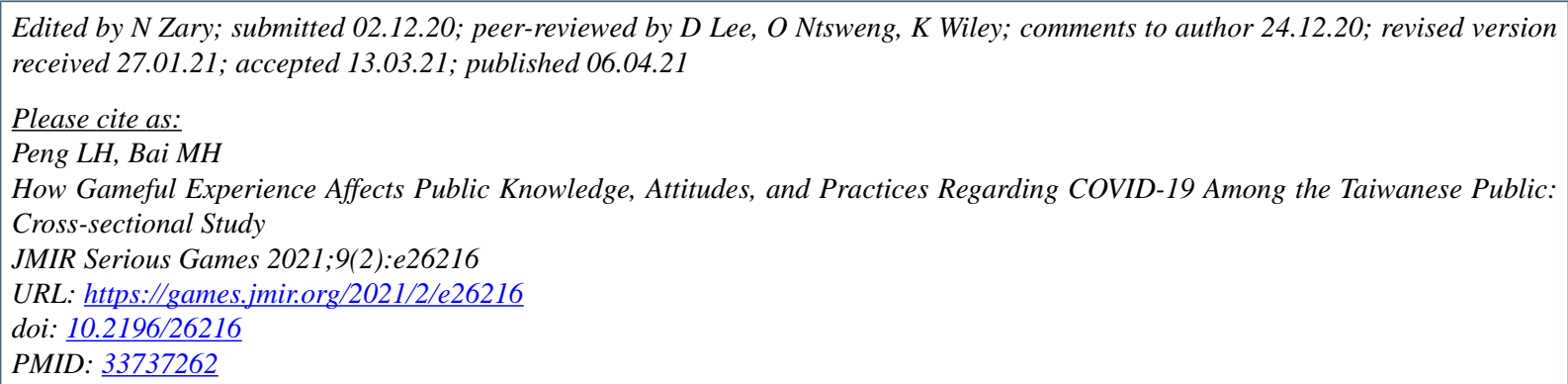

CLi-Hsun Peng, Ming-Han Bai. Originally published in JMIR Serious Games (http://games.jmir.org), 06.04.2021. This is an open-access article distributed under the terms of the Creative Commons Attribution License (https://creativecommons.org/licenses/by/4.0/), which permits unrestricted use, distribution, and reproduction in any medium, provided the original work, first published in JMIR Serious Games, is properly cited. The complete bibliographic information, a link to the original publication on http://games.jmir.org, as well as this copyright and license information must be included. 